\title{
Green-synthesis of $\mathrm{Ag}_{2} \mathrm{O}$ nanoparticles for antimicrobial assays**
}

https://doi.org/10.1515/jmbm-2021-0024

Received Jul 20, 2021; accepted Oct 05, 2021

\begin{abstract}
Silver oxide nanoparticles $\left(\mathrm{Ag}_{2} \mathrm{O}\right.$ NPs) in the aqueous colloidal state were synthesized using the green method. Aqueous silver nitrate was prepared and mixed jointly with an aqueous extract of Lawsonia inermis (henna) leaf and heated with stirring at $75^{\circ} \mathrm{C}$ for $1 \mathrm{~h}$. Then, an aqueous colloidal solution of $\mathrm{Ag}_{2} \mathrm{O}$ NPs with a dark brown colour is forming. The physicochemical characterization of $\mathrm{Ag}_{2} \mathrm{O}$ NPs was studied using different techniques. A polycrystalline structure of $\left(\mathrm{Ag}_{2} \mathrm{O} / \mathrm{Ag}\right)$ in face-centred cubic and $\mathrm{cu}$ bic phases was revealing via grazing incident X-ray diffraction (GIXRD) patterns. Energy-dispersive X-ray analysis (EDX) spectra confirmed GIXRD results through peaks corresponding to the silver and oxygen elements making up the accurate composition of the silver oxide. UV-Vis absorbance peak of the localized surface plasmon resonance (SPR) appeared at the visible region and exhibited a blueshift at $\sim 425 \mathrm{~nm}$ with an energy bandgap $\sim 2.8 \mathrm{eV}$. The surface morphology and the size of the silver nanoparticles were analyzed using high resolution (FE-SEM) microscopy. FTIR spectra of $\mathrm{Ag}_{2} \mathrm{O}$ NPs has showed a shift in the bands compared to those produced by aqueous extract of the henna leaf (only). (0.4 molars) $\mathrm{Ag}_{2} \mathrm{O}$ NPs has showed excellent antimicrobial activity assays against all the pathogens microbe's strains. Henna plant extract (only) has showed poor activity compared to $\mathrm{Ag}_{2} \mathrm{O}$ NPs. In comparison, the inhibition zone diameter of the gram-negative Bacteria is more considerable than the gram-positive bacteria. Moreover, $\mathrm{Ag}_{2} \mathrm{O}$ NPs activity against Bacteria is more prominent than fungi.
\end{abstract}

Keywords: Antimicrobial, Lawsonia inermis, $\mathrm{Ag}_{2} \mathrm{O}$ NPs, fungi.

\section{Introduction}

In recent years, nanotechnology development was flourished, and green chemicals were used to synthesize various metallic nanoparticles without any external chemicals that might pollute the atmosphere $[1,2,3]$. As a comparison to other methods, the green approach is more advantageous due to its simplicity, cleanliness and results in the costeffective development of nanoparticles with defined properties [4, 5]. Starch, proteins, phenolic acids, terpenoids, carbohydrates, alkaloids, and polyphenols, are bioactive compounds found in plant extracts. These compounds can help the form nanoparticles by reducing and capping agents $[6,7]$. Among the numerous metallic nanoparticles investigated, the noble metal silver occupies a prominent position in nanomaterial science due to its specific properties applied to various fields. The antimicrobial properties of $\mathrm{Ag}_{2} \mathrm{O}$ NPs, commonly used in antibacterial and antifungal applications, are due to electrical variations when interacting with Bacterial membrane. These modifications improve further the reactivity of Ag nanoparticle surfaces [8]. Furthermore, metal nanoparticles' in vitro bactericidal efficacy enhances by their stability in conditions of culture and their ability to remain effective for long periods without decomposition [9]. The antibacterial activity of the nanoparticles is probably due to electrostatic interaction with the cell membrane of the Bacteria and internalization of the $\mathrm{Ag}_{2} \mathrm{O}$ NPs in the microbial cell, which leads to the production of reactive oxygen species (ROS) and membrane damage [10]. ROS are solid oxidizing agents that oxidize lipids and proteins present in the cell and cause DNA damage. It causes oxidative stress and disrupts normal cellular functions due to the inactivity of essential proteins, and disarray in replication and protein synthesis leads to DNA damage. It also alters or inhibits the metabolism or respiratory cycles of the Bacteria. These mechanisms finally lead to cell death and, therefore, suppression of Bacterial growth

\footnotetext{
**Paper included in the Special Issue entitled: Proceedings of Mustansiriyah International Conference on Applied Physics - 2021 (MICAP-

2021)
}

^Corresponding Author: Ali Abdullah Fayyadh: Department of physics, college of science, Wasit University, Wasit, Iraq. E-mail: alia224@uowasit.edu.iq

Muneer H. Jaduaa Alzubaidy: Department of physics, college of science, Wasit University, Wasit, Iraq. 
[11, 12]. Xiang et al. found that AgNPs can significantly inhibit the growth and development of fungi hyphae, destroy the cell membrane permeability of fungi hyphae, inhibit the synthesis of soluble proteins, destroy DNA structure, and inhibit DNA replication [13]. Sondi and Salopek-Sondi investigated the antimicrobial activity of silver nanoparticles against $E$. coli as a model for gram-negative Bacteria. Also, they report another antimicrobial activity mechanism that depends on the electrostatic attraction between negatively charged Bacterial cells and positively charged $\mathrm{Ag}$ NPs [9]. Panacek et al. discovered that $\mathrm{Ag}_{2} \mathrm{O}$ NPs have excellent antimicrobial activity against gram-negative and gram-positive Bacteria, and the mechanism depends on the size of silver particles [14]. Flores-Lopez et al. synthesized $\mathrm{Ag}_{2} \mathrm{O} / \mathrm{Ag}$ nanoparticles using Aloe vera plant extract via a green synthesis method. It shows excellent antibacterial activity against gram-negative and gram-positive Bacteria E. coli and S. aureus. Moreover, high antifungal activity against some various species from Candida [15]. Recently, Ghojavand et al. successfully synthesized AgNPs from an aqueous extract of Felty germander using a green approach, and the resulting AgNPs has an excellent antifungal activity [16]. This paper aims to provide an alternative eco-friendly method to obtain silver oxide nanoparticles species and assess their bactericidal activity. Also, reducing the cost of synthesizing $\mathrm{Ag}_{2} \mathrm{O}$ NPs with a green eco-friendly method, using a low-cost and commercial Lawsonia inermis (henna) extract. $\left(\mathrm{Ag}_{2} \mathrm{O}\right.$ NPs) shows excellent antimicrobial activity against some microbial pathogen strains (e.g., $S$-aureus, P-aeruginosa, E-coli, Penicillium spp., Aspergillus spp., and Candida albicans).

\section{Material and methods}

\subsection{Preparation of extract}

Collection fresh Lawsonia inermis (henna) leaves from nurseries of the plant in Wasit/Iraq. It is clean with tap water, gently brushed to remove soil and other dust particles, and washed with distilled water. Then, the henna leaves were sliced into small pieces and distributed evenly to facilitate homogenous drying. Henna leaves were dehydrated via the shade air-dry method during the summer in dry conditions and shaded areas to prevent microbial fermentation and subsequent degradation of metabolites of plant material for ten days. The dry leaves parts grinding into smaller particles using a mechanical grinder to shred the plant tissues to powder. The quantity of $2 \mathrm{~g}$ of henna powder was dissolved in $100 \mathrm{ml}$ distilled water at $\mathrm{pH} 4.2$ by heated and stirred at $\left(50^{\circ} \mathrm{C}\right)$ for $1 \mathrm{~h}$. using a hot plate stirrer. The henna solution was filtered via vacuum filtration using a Buchner funnel, a side-arm flask, and filter paper. Finally, keeping the final aqueous solution at room temperature for additional usage.

\subsection{Green-synthesis of $\mathrm{Ag}_{2} \mathrm{O} \mathrm{NPs}$}

Silver nitrate $\left(\mathrm{AgNO}_{3}\right)$ provided by (Glentham life sciences LTD, U.K.) and plant extract of Lawsonia inermis (henna) were employed to synthesize silver oxide nanoparticles via the green-synthesis approach. One molar of aqueous silver nitrate solution was synthesized by dissolving $\mathrm{AgNO}_{3}$ in 100 $\mathrm{ml}$ distilled water. The dissolution was performed at $\left(75^{\circ} \mathrm{C}\right)$ under enthusiastic mixing at $(700 \mathrm{rpm})$ for $1 \mathrm{~h}$. Then, $100 \mathrm{ml}$ of the henna plant extract was slowly added to $100 \mathrm{ml}$ of the silver nitrate aqueous solution, continuously stirred and heated at $\left(75^{\circ} \mathrm{C}\right)$ for $1 \mathrm{~h}$. After that, a dark brown coloured aqueous colloidal mixture of the green synthesized $\mathrm{Ag}_{2} \mathrm{O}$ NPs is forming. To study the crystal structure, surface morphology, and identify the elemental composition of $\mathrm{Ag}_{2} \mathrm{O}$ NPs by GIXRD, FE-SEM / EDX techniques, the final colloidal solution of $\mathrm{Ag}_{2} \mathrm{O}$ NPs was deposited on a glass substrate to form a layer film via the drop-casting method. The dropcasting process was carried under a temperature below $(60$ $\left.{ }^{\circ} \mathrm{C}\right)$ using a micropipette and hot plate stirrer.

\subsection{Preparation of bacteria and fungi for sensitivity test}

The antimicrobial activity of the colloidal $\mathrm{Ag}_{2} \mathrm{O}$ NPs and henna plant extract was studied using an agar well diffusion method [17, 18]. The Mueller Hinton agar (MHA) medium was prepared for the antimicrobial test since it is the best medium for developing the most pathogenic microbes. Three types of pathogenic Bacterial strains: gram-positive Staphylococcus aureus, gramnegative Pseudomonas aeruginosa, and Escherichia coli, were used to study the antibacterial assays. Also, three types of pathogenic fungal strains: Penicillium spp., Candida albicans, and Aspergillus spp, were used to study the antifungal assays. To stimulate the microbes, they were grown in a rich medium culture such as tryptic soy agar and incubated at $\left(37^{\circ} \mathrm{C}\right)$ overnight for the sensitivity test. After that, The microbes at $25^{\circ} \mathrm{C}$ dissolved in physiological saline solution $(0.85 \%)$. Then, the comparing between the turbidity of the suspension and (1/2) McFarland turbidity standard tube equal to $\left(10^{8} \mathrm{CFU} / \mathrm{ml}\right)$ were made; McFarland was synthesized according to MacFaddin $\left(2 \times 10^{3}\right.$ to 9.950) $\mathrm{ml}$ of (1\%) sulphuric acid $\left(\mathrm{H}_{2} \mathrm{SO}_{4}\right)$ with $(0.050 \mathrm{ml})$ 
of $(1.176 \%)$ barium chloride dehydrate $\left(\mathrm{BaCl}_{2}-2 \mathrm{H}_{2} \mathrm{O}\right)$. The norm liquidates into $(5 \mathrm{ml})$ screw-capped tubes of the same size used in this process, packed in the dark at room temperature, and shaken before use. After that, the microbe's suspension was swabbed on the superficies of the MHA under sterile conditions using the swabbing method. After the microbes dry up, make a well in the MHA with a diameter of $6 \mathrm{~mm}$. The wells were puncturing with the backside of a sterile blue micropipette tip. $100 \mathrm{ml}$ of the antimicrobial agent (i.e., $\mathrm{Ag}_{2} \mathrm{O}$ NPs or henna plant extract) is introduced into the well using a micropipette. All the Bacteria strains were incubating in dishes for $18 \mathrm{~h}$. (not more than $24 \mathrm{~h}$ ) at $\left(37^{\circ} \mathrm{C}\right)$ overnight. While the fungi strains, Penicillium spp and Aspergillus spp at $\left(25 \pm 2{ }^{\circ} \mathrm{C}\right)$ for seven days, and Candida albicans at $\left(25 \pm 2{ }^{\circ} \mathrm{C}\right)$ for four days old culture. Finally, the positive growth inhibition zones diameter around each well was read in $\mathrm{mm}$.

\subsection{Characterization of green synthesized $\mathrm{Ag}_{2} \mathrm{O} \mathrm{NPs}$}

Different techniques were used to study the physicochemical characterization of the green synthesized $\mathrm{Ag}_{2} \mathrm{O}$ NPs. The crystalline structure of $\mathrm{Ag}_{2} \mathrm{O}$ NPs layer film was analyzed using GIXRD model PHILIPS X-Ray Diffractometer, PW 1730, which measures intensity as a function of Bragg's angle, subject to the following conditions: Copper $(\mathrm{Cu})$ is the target, with a wavelength of $1.54060^{\circ} \mathrm{A}$, a current of $30 \mathrm{~mA}$, and a voltage of $40 \mathrm{kV}$. Scanning angle $2 \Theta$ (change) in the range of (10-80) degrees at a speed of ( 5 degrees per minute). The surface morphology, particle size, and identify the elemental composition of the $\mathrm{Ag}_{2} \mathrm{O}$ NPs layer film was analyzed using field emission-scanning electron microscopy (FE-SEM / EDX) model TESCAN Mira3. While, the FTIR spectra of the $\mathrm{Ag}_{2} \mathrm{O}$ NPs colloidal solution in the wavenumber range of $400-4000 \mathrm{~cm}^{-1}$ were confirmed by Fouriertransform infrared spectroscopy (FTIR) model (IRAffinity-1, SHIMADZU). Moreover, evaluate the optical properties by UV-Vis spectrophotometer 1900i, type (SHIMADZU).

\section{Result and discussion}

\subsection{GIXRD analysis}

Silver oxide nanoparticles $\left(\mathrm{Ag}_{2} \mathrm{O}\right.$ NPs) layer film crystal structure was analyzed using the GIXRD technique. This technique used to obtain small incident Bragg diffraction angles at surface layers and near regions is the explicit form of X-ray diffraction of grazing incidence. So that, it is used to study the surface of the $\mathrm{Ag}_{2} \mathrm{O}$ NPs layer film, not the glass, because wave penetration is limited. Figure 1 shows GIXRD patterns sharp peaks of the $\left(\mathrm{Ag}_{2} \mathrm{O} \mathrm{NPs}\right)$ layer film in a polycrystalline structure.

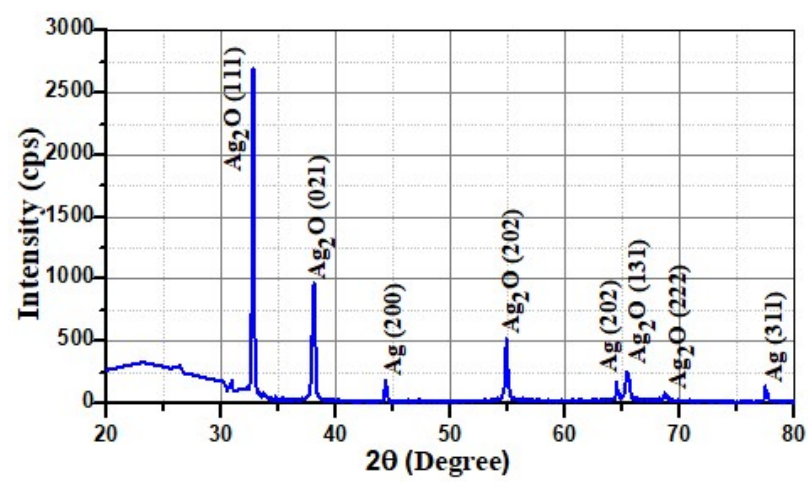

Figure 1: Grazing incident XRD patterns of $\mathrm{Ag}_{2} \mathrm{O}$ NPs.

All the diffraction peaks at $2 \Theta$ equal $32.78^{\circ}, 38.07^{\circ}$, $54.86^{\circ}, 65.35^{\circ}$, and $68.67^{\circ}$ were observed in the GIXRD spectrum, which can be well-matched with the cubic phase structure and correspond to (111), (200), (220), (311), and (222) crystal planes $\mathrm{Ag}_{2} \mathrm{O}$ NPs of face-centred cubic (FCC), also are well-matched with the JCPDS card number (01-0761393) [19]. Besides, GIXRD patterns exhibited diffraction peaks at $2 \Theta$ equal $44.27^{\circ}, 64.45^{\circ}$, and $77.42^{\circ}$ can be wellmatched with the cubic phase structure and correspond to (200), (220), and (311) crystal planes, respectively of cubic Ag NPs which is well-matched with the JCPDS card number (00-004-0783) [20]. Table 1 illustrates the structural properties of the green synthesized $\mathrm{Ag}_{2} \mathrm{O}$ NPs. The average crystallite size of the maximum three peaks was determined utilizing the Debye-Scherer Eq. (1) and found to be $~ 37.4$ nm.

$$
\mathrm{D}=\mathrm{K} \lambda /(\beta \cos \theta)
$$

Here, $\mathrm{D}$ is the crystallite size, $\lambda=1.5406^{\circ} \mathrm{A}$ is the wavelength of $\mathrm{X}$-ray $\mathrm{Cu}$-K $\alpha$ radiation, $\beta$ is the full width at half maximum (FWHM), $\Theta$ is the diffraction angle (Bragg's angle), and $\mathrm{K}$ is the crystallite form constant ( 0.94 for spherical shapes) [21, 22]. The distance between the crystalline levels (d) was measure using Eq. (2).

$$
n \lambda=2 d \sin \theta
$$

Here, $d$ is the distance between atomic layers in a crystal, $\lambda$ is the wavelength of the incident $\mathrm{X}$-ray beam, $2 \Theta$ is the diffraction angle (Bragg's angle), and $\mathrm{n}$ is the order of the diffraction peak $[23,24,25]$. 
Table 1: Structural properties of green synthesized $\mathrm{Ag}_{2} \mathrm{O}$ NPs.

\begin{tabular}{llllll}
\hline $\begin{array}{l}2 \Theta \\
\text { (Deg.) }\end{array}$ & $\begin{array}{l}\text { FWHM } \\
\text { (Deg.) }\end{array}$ & hkl & dhkl.(Å) & $\begin{array}{l}\text { Crystallite } \\
\text { Size }(\mathrm{nm})\end{array}$ & JCPDS No. \\
\hline 32.783 & 0.1814 & 111 & 2.7299 & 45.65 & $01-076-1393$ \\
38.079 & 0.2861 & 200 & 2.3620 & 29.374 & (face-centred cubic) $\mathrm{Ag}_{2} \mathrm{O}$ \\
54.863 & 0.2401 & 220 & 1.6719 & 37.279 & $00-004-0783$ (cubic) Ag \\
\hline
\end{tabular}

\subsection{FE-SEM / EDX analysis}

Surface morphology of the green-synthesized $\left(\mathrm{Ag}_{2} \mathrm{O} \mathrm{NPs}\right)$ layer film validated using a high-resolution microscope (FE$\mathrm{SEM})$. Figure 2 shows the FE-SEM images of the $\mathrm{Ag}_{2} \mathrm{O} \mathrm{NPs}$ with different magnifications. The $\mathrm{Ag}$ and $\mathrm{Ag}_{2} \mathrm{O}$ NPs were shaped in oval and spherical with aggregation and lacked monodispersity. Figure $2 \mathrm{~d}$ gives the average particle size distribution of $\mathrm{Ag} / \mathrm{Ag}_{2} \mathrm{O} \mathrm{NPs}$ around $\sim 39.1 \mathrm{~nm}$. It was reported a similar result in a previous study [19]. Since each element in $\mathrm{Ag}_{2} \mathrm{O}$ NPs has a distinct atomic structure and it emits a spectrum with a specific collection of peaks. Therefore, the $\mathrm{X}$-ray energy dispersive spectroscopy (EDX) technique is employed to confirm GIXRD results.

Figure 3 gives peaks corresponding to silver and oxygen elements of silver oxide nanoparticles. Due to surface plasmon resonance, a strong absorption peak in the silver (Ag L $\alpha 1$ ) was observed at $3 \mathrm{KeV}$, confirming the existence of silver nanocrystals. Also, a weak absorption peak in the oxygen (O K $\alpha 1$ ), sodium (Na K $\alpha 1$ ), and chlorine (CL L $\alpha 1)$ regions were observed at $0.5,1.06$, and $2.15 \mathrm{KeV}$, respectively. These elements are inherently present in the henna plant tissues. This result agrees with $[26,27,28]$.

Figures $4 \mathrm{a}$, b, and c show the dot mapping corresponds to silver and oxygen distribution. While. Figure $4 \mathrm{~d}$ shows the dot mapping corresponding to silver and oxygen distribution combine with (FE-SEM) surface morphology of $\mathrm{Ag}_{2} \mathrm{O}$ NPs, as shown in Figure 2c. Besides, silver and oxygen elements with a normalized concentration in weight percentage are equal to $78.48 \%$ and $21.52 \%$, respectively. Also, the atomic weight percentage of silver and oxygen elements is $36.66 \%$ and $63.34 \%$, respectively. A weak oxygen signal is due to X-ray emission from carbohydrates, proteins, and enzymes in the henna leaves [29]. Furthermore, the formation of silver oxide nanoparticles after synthesizing $\mathrm{Ag}_{2} \mathrm{O}$ NPs reacts with water in the solution is due to the nanoparticles' high surface-to-volume ratio, making them highly reactive [30].

\subsection{FTIR analysis}

The FTIR spectroscopy in the wavenumber range 400-4000 $\mathrm{cm}^{-1}$ was used to analyze the chemical bonds and functional groups of both henna plant extract (only) and colloidal $\mathrm{Ag}_{2} \mathrm{O}$ NPs, as shown in Figure 5. FTIR spectra of $\mathrm{Ag}_{2} \mathrm{O}$ NPs showed a shift in the bands compared to those produced by henna plant extract (only). The functional groups' change caused by adding henna plant extract to silver nitrate to synthesize $\mathrm{Ag}_{2} \mathrm{O}$ NPs. Henna plant extract (only) shows several peaks of the major functional groups appearing at $3255.84,2360.87$, and $1647.20 \mathrm{~cm}^{-1}$. While colloidal $\mathrm{Ag}_{2} \mathrm{O}$ NPs shows a shift in the bands at $3268.95,1616.59$, and $2342.63 \mathrm{~cm}^{-1}$. All peaks correspond to the stretching vibration of the hydroxyl group (H-bonded O-H stretch) [31, 32], $\mathrm{O}-\mathrm{H}$ bending vibration of an adsorbed water molecule on the surface of $\mathrm{Ag}_{2} \mathrm{O}$ NPs, which may be essential for antimicrobial assays [31,33], and weak stretching vibrations $\mathrm{C}=\mathrm{C}$ [34], respectively. Furthermore, $\mathrm{Ag}_{2} \mathrm{O}$ NPs show an $\mathrm{Ag}$ $O$ bending mode of vibration at $(715.31) \mathrm{cm}^{-1}$, confirming metal-oxygen bonding formation $[9,31,35,36]$.

\subsection{UV-Vis analysis}

Figure 6a shows the UV-Vis absorption spectrum of colloidal $\mathrm{Ag}_{2} \mathrm{O}$ NPs. The presence of a narrow absorption peak agrees with the nanocrystalline nature of the $\mathrm{Ag}_{2} \mathrm{O} \mathrm{NPs} \mathrm{sam-}$ ple. The intensity absorbance band of the localized surface plasmon resonance (SPR) appeared at the visible region and exhibited a blueshift at $\sim 425 \mathrm{~nm}$ due to Ag nanoparticles' small particle size [37]. The energy bandgap $\left(E_{g}\right)$ of colloidal $\mathrm{Ag}_{2} \mathrm{O}$ NPs were accessed using Tauc's Eqs. (3) and (4), and the direct bandgap was estimated by extrapolating a straight line on the energy axis for $\mathrm{Ag}_{2} \mathrm{O}$ NPs.

$$
\alpha h v=\alpha^{0}\left(h v-E_{g}\right)^{n}
$$

$$
\alpha=4 \pi k / \lambda
$$

Where $\mathrm{E}_{\mathrm{g}}$ is optical band gap energy, $h v$ is photon energy and equal to $1240 \mathrm{ev} / \lambda, \alpha$ is absorption coefficient, $\lambda$ 


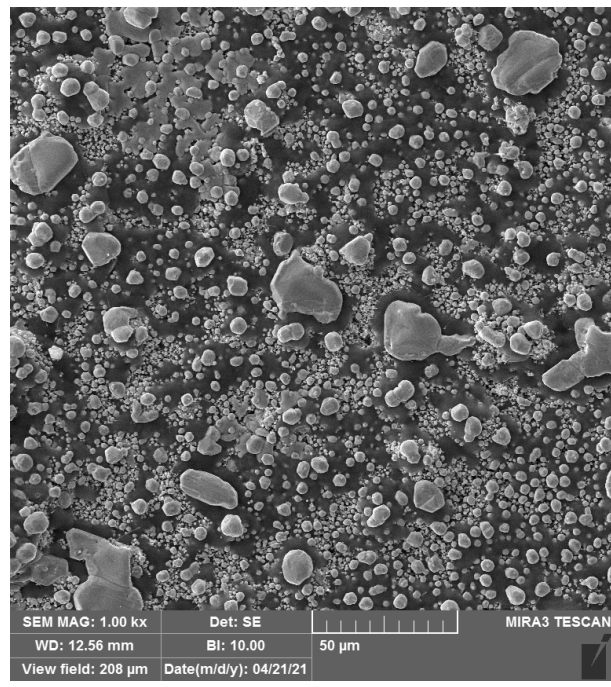

(a)

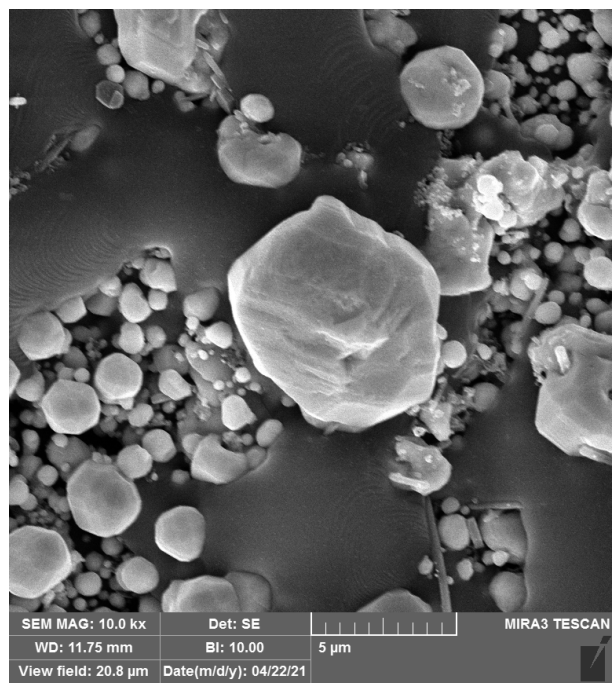

(c)

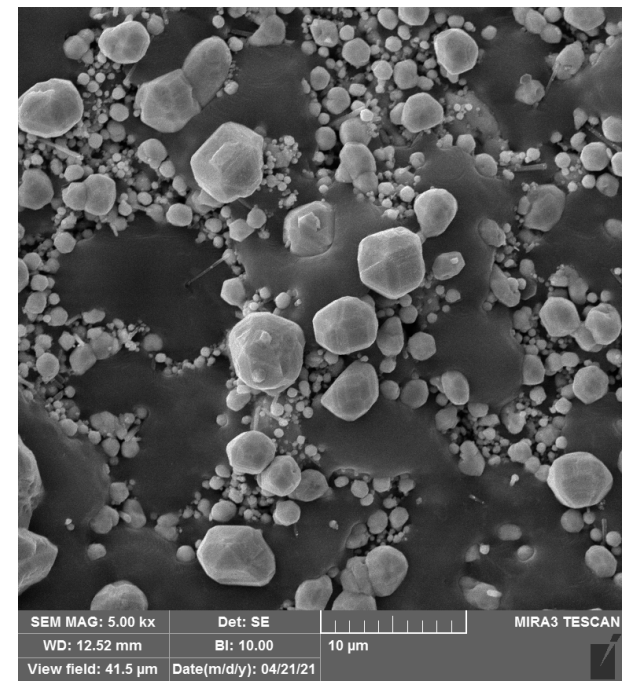

(b)

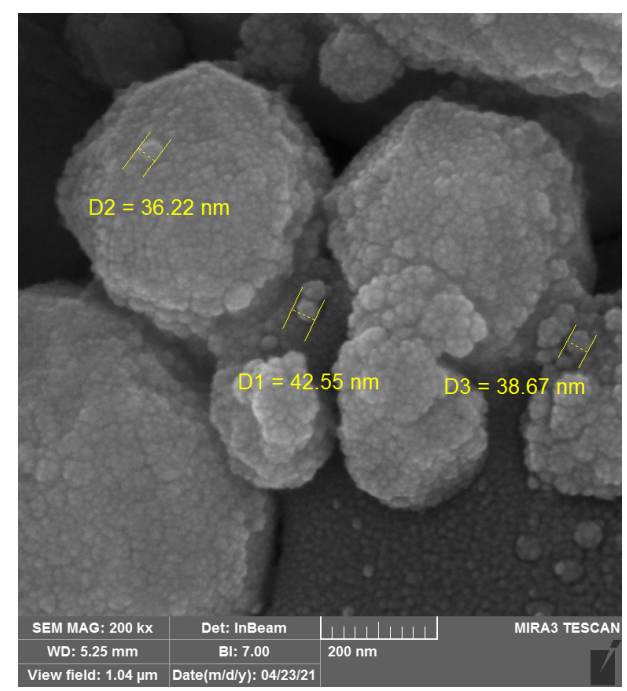

(d)

Figure 2: FE-SEM images describe the surface morphology and particle size of $\mathrm{Ag}_{2} \mathrm{O}$ NPs with four different magnifications (a) $1 \mathrm{KX}$, (b) $5 \mathrm{KX}$, (c) $10 \mathrm{KX}$, and (d) $200 \mathrm{KX}$.

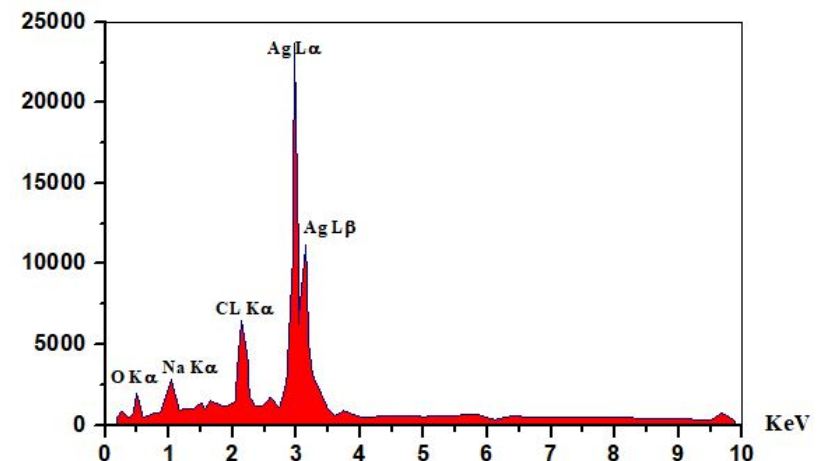

Figure 3: EDX elemental spectrum of $\mathrm{Ag}_{2} \mathrm{O}$ NPs. is the wavelength (nm), $\mathrm{k}$ is absorbance, $\alpha^{0}=$ band tailing parameter (constant), $\mathrm{h}$, is plank's constant, $v$ is radiation frequency, $\mathrm{n}$ is the power factor for transition mode, it has values $1 / 2,2,3 / 2$, and 3 for various types of transition, i.e., not allowed, allowed, and forbidden, respectively [32, 33]. In this paper, $n=1 / 2$ gave the best fit of our experimental data. Therefore, the obtained value of $E_{g}$ by plotting $(\alpha h v)^{2}$ vs $h v$ as shown in Figure $6 \mathrm{~b}$, and $2.85 \mathrm{eV}$, was the $\mathrm{E}_{\mathrm{g}}$ value of $\mathrm{Ag}_{2} \mathrm{O}$ NPs. Based on the above findings, $\mathrm{Ag}_{2} \mathrm{O}$ NPs colloidal solution energy bandgap is higher when compared with the reported values; it may be due to the particle size and quantum confinement effect [38]. 


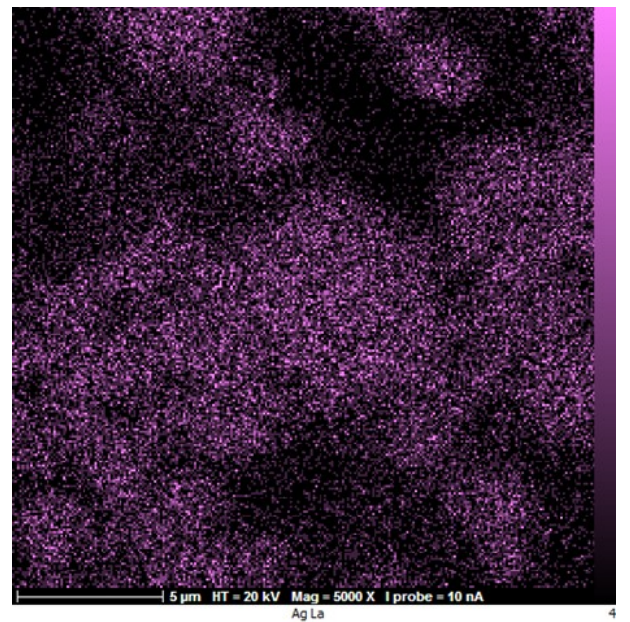

(a)

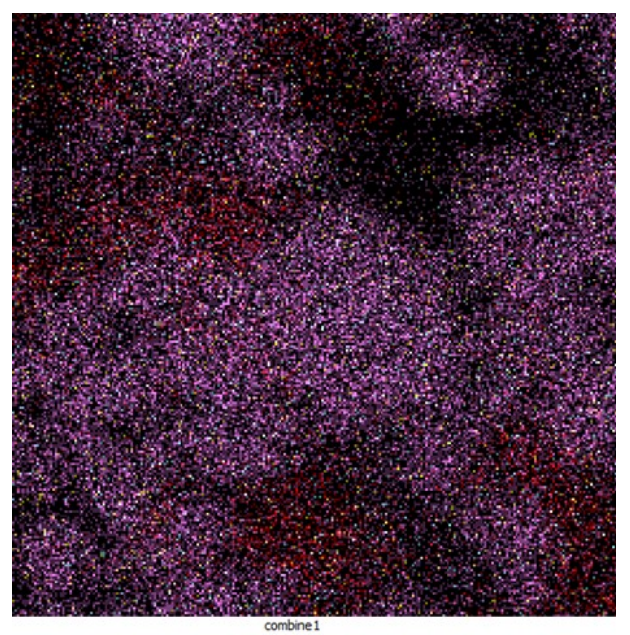

(c)

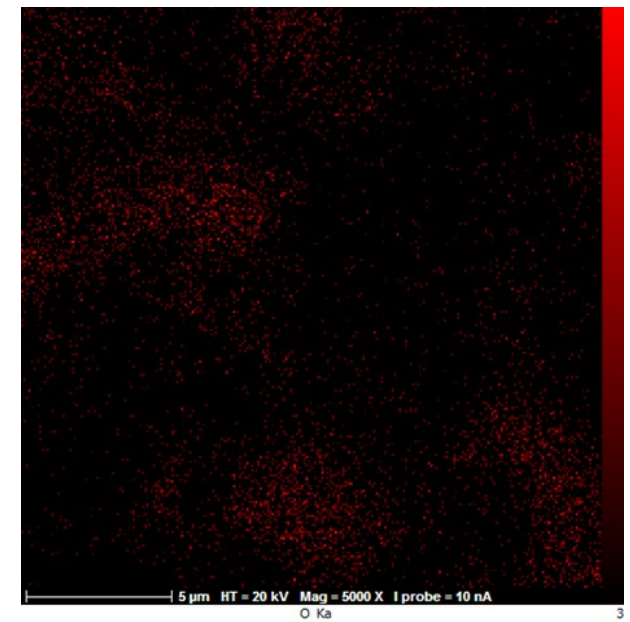

(b)

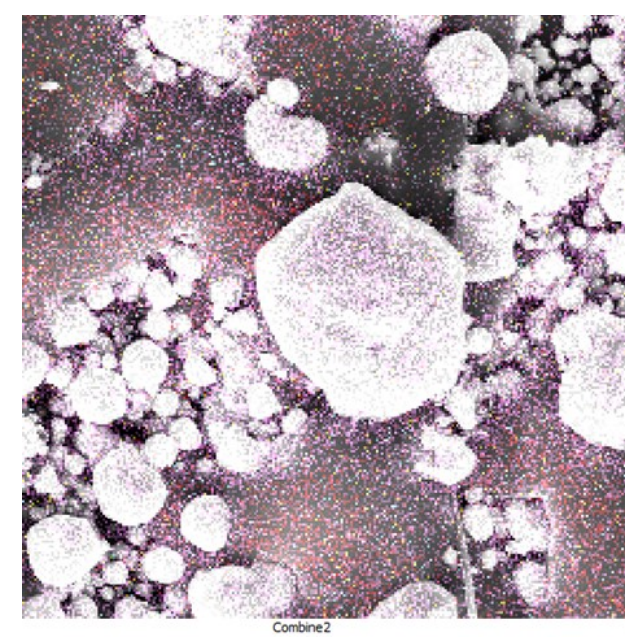

(d)

Figure 4: FE-SEM dot maps of $\mathrm{Ag}_{2} \mathrm{O}$ NPs surface morphology corresponding to; (a) AgNPs distribution, (b) oxygen distribution, (c) combine of silver and oxygen elements distribution, and (d) silver and oxygen elements distribution combine with FE-SEM image.

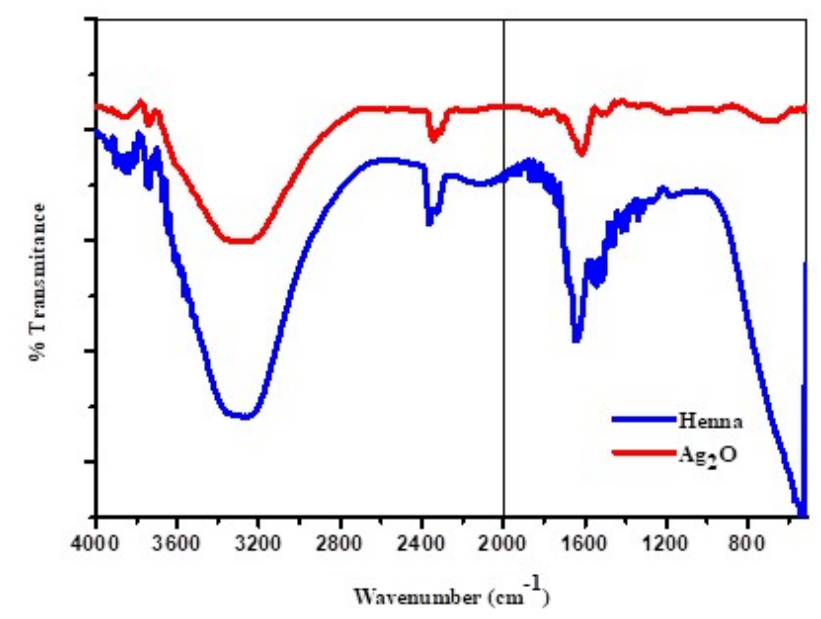

Figure 5: FTIR spectra of $\mathrm{Ag}_{2} \mathrm{O}$ NPs and henna plant extract.

\subsection{Antimicrobial assays}

The green synthesized $\mathrm{Ag}_{2} \mathrm{O}$ NPs colloidal solution and Lawsonia inermis (henna) plant extract was tested in this work against pathogenic microbial (Bacteria-like; $S$-aureus, $P$-aeruginosa, and E-coli) and (fungal-like; Penicillium spp., Aspergillus spp., and Candida albicans) to ensure its antimicrobial activity. In this test, $(0.4 \mathrm{M})$ concentration of $\mathrm{Ag}_{2} \mathrm{O}$ NPs was used, because one molar of $\mathrm{Ag}_{2} \mathrm{O}$ NPs gives a huge inhibition zone diameter, leading to an overlap in the inhibition zones in one petri dish. Notably, henna plant extract (only) also showed a potential inhibition against microbial pathogens. But the $\mathrm{Ag}_{2} \mathrm{O}$ NPs shows excellent antimicrobial activity compared to henna plant extract (only) (see Figures 7 and 8). The microbial halo formed around the well indicates the green synthesized $\mathrm{Ag}_{2} \mathrm{O}$ NPs have ex- 


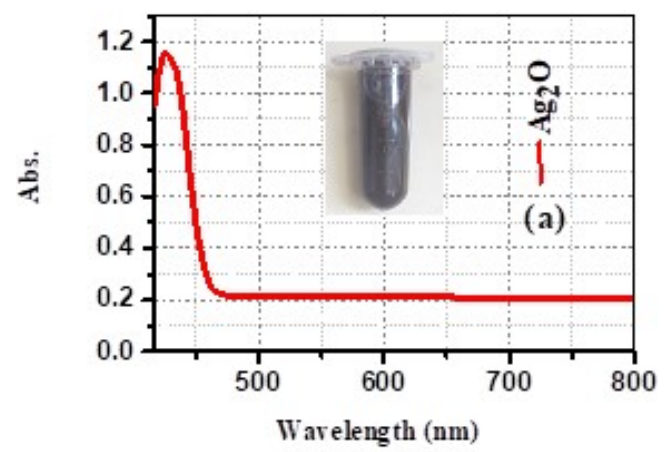

(a)

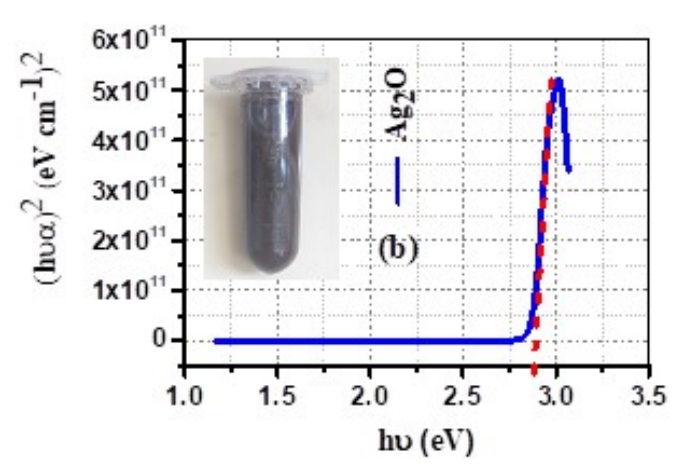

(b)

Figure 6: UV-Vis spectrophotometer of green-synthesized $\mathrm{Ag}_{2} \mathrm{O} \mathrm{NPs}$, (a) Absorption spectrum, and (b) energy bandgap $\left(E_{g}\right)$.

cellent antimicrobial activity. The $\mathrm{Ag}_{2} \mathrm{O}$ NPs react with the microbe's cell wall and inhibit the respiratory process by interacting Ag NPs with the respiratory enzymes which are presented in the microbial cell walls. As shown in Figure 7, gram-negative Bacteria E.coli and P. Aeruginosa shows large inhibition zone diameters ( $38 \mathrm{~mm})$ and $(37 \mathrm{~mm})$, respectively. In contrast, gram-positive $S$. aureus Bacteria shows a small inhibition zone diameter (32mm). The difference in the inhibition diameter is attributing to the thickness of the Bacteria cell walls. Gram-negative Bacteria have a thin layer of flexible lipopolysaccharides at the exterior. In contrast, the cell wall in gram-positive Bacteria is principally composed of a thick layer from zwitterionic and rigid peptidoglycan [39].

In the antifungal assay test, four different molar concentrations (0.1,0.2,0.3, and $0.4 \mathrm{M}$ ) of $\mathrm{Ag}_{2} \mathrm{O}$ NPs used against Penicillium spp. and Aspergillus spp. In addition, (0.4 M) of $\mathrm{Ag}_{2} \mathrm{O}$ NPs were used individually in Candida albicans. As shown in Figure 8, a large inhibition zone diameter is seen at (0.4M) $\mathrm{Ag}_{2} \mathrm{O}$ NPs against Candida albicans more than the other two types of fungus. Also, notice an increase in the diameter of the inhibition zone as the molar concentration of silver oxide nanoparticles increases (see Table 2). Furthermore, this result shows excellent antifungal assays of $(0.4$

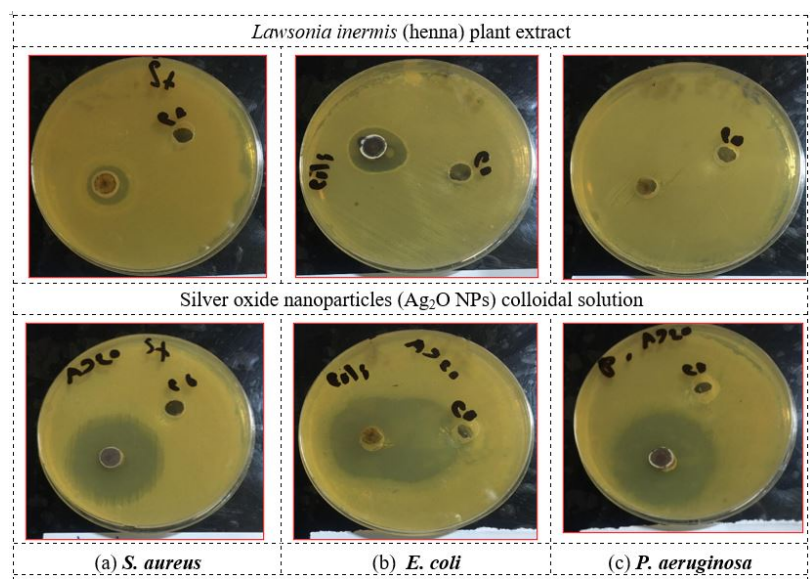

Figure 7: Antibacterial assay test using well diffusion method of Lawsonia inermis (henna) plant extract and $\mathrm{Ag}_{2} \mathrm{O}$ NPs against (a) $S$. aureus, (b) E. coli, (c) P. aeruginosa.

M) $\mathrm{Ag}_{2} \mathrm{O}$ NPs against the three pathogens funges strains better than henna plant extract (only). Moreover, it offers an inhibition zone diameter against Bacteria larger than fungi. The X-ray and FE-SEM tests found that the silver oxide synthesized by the green approach is within the nanoscale range. Thus, the mechanism of antimicrobial activity in the current study is attributed to the high surface area to volume ratio between Ag NPs and microbes. Also, free radicals such as hydroxyl radicals as confirmed by FTIR, the release of Ag+ ions, and reactive oxygen species (ROS) production.

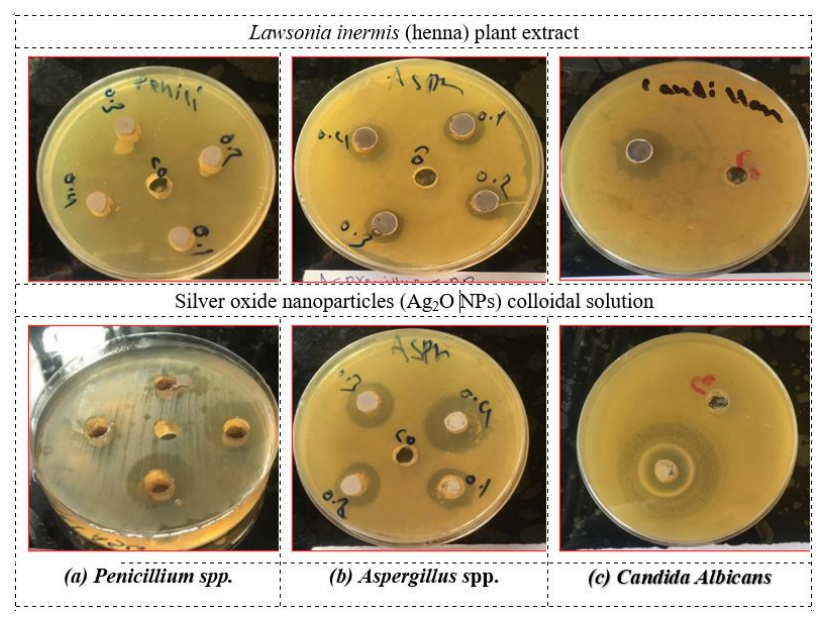

Figure 8: Antifungal assay test using well diffusion method of Lawsonia inermis (henna) plant extract $\mathrm{Ag}_{2} \mathrm{O}$ NPs against (a) Penicillium spp., (b) Aspergillus spp., and (c) Candida albicans. 
Table 2: Antifungal inhibition zone diameter of henna plant extract and $\mathrm{Ag}_{2} \mathrm{O}$ NPs against Penicillium spp., Aspergillus spp., and Candida albicans.

\begin{tabular}{|c|c|c|c|c|c|c|c|c|c|}
\hline \multirow{2}{*}{ sample } & \multicolumn{4}{|c|}{ Penicillium spp. } & \multicolumn{4}{|c|}{ Aspergillus spp. } & \multirow{2}{*}{ Candida albicans } \\
\hline & $0.4 \mathrm{M}$ & $0.3 \mathrm{M}$ & $0.2 \mathrm{M}$ & $0.1 \mathrm{M}$ & $0.4 \mathrm{M}$ & $0.3 \mathrm{M}$ & $0.2 \mathrm{M}$ & $0.1 \mathrm{M}$ & \\
\hline Lawsonia inermis & 0 & 0 & 0 & 0 & 5 & 4 & 4 & 4 & 5 \\
\hline $\mathrm{Ag}_{2} \mathrm{O} \mathrm{NPs}$ & 16 & 14 & 5 & 2 & 15 & 9 & 8 & 7 & 21 \\
\hline
\end{tabular}

\section{Conclusion}

The green-synthesis approach successfully prepared silver oxide nanoparticles. GIXRD pattern of the $\mathrm{Ag}_{2} \mathrm{O}$ NPs layer film reveals two phases; face-centred cubic represents $\mathrm{Ag}_{2} \mathrm{O}$ NPs, and cubic represent Ag NPs with an average crystallite size of $\sim 37 \mathrm{~nm}$. FE-SEM analysis illustrates that most particles were spherical with aggregation and lacked monodispersity with an average particle size of $\sim 39 \mathrm{~nm}$. EDX analysis confirms the GIXRD result; the energy-dispersive Xray spectrum shows a strong absorption peak in the silver region ( $\mathrm{L} \alpha 1)$ was observed at $3 \mathrm{KeV}$, confirming the existence of silver nanocrystals. Also, a weak absorption peak in the oxygen region (K $\alpha 1)$ was observed at $0.5 \mathrm{KeV}$, confirming the presence of oxygen element. FTIR analysis confirmed fatty acids and carbohydrates related to Lawsonia inermis plant extract and other hydroxyl radicals in $\mathrm{Ag}_{2} \mathrm{O}$ NPs. UV-Vis absorbance peak of the localized surface plasmon resonance (SPR) appeared at the visible region and exhibited a blueshift at $(\sim 425 \mathrm{~nm})$ due to $\mathrm{Ag}$ nanoparticles' small particle size. Based on the above findings, $\mathrm{Ag}_{2} \mathrm{O}$ NPs colloidal solution energy bandgap is significant $(\sim 2.8$ $\mathrm{eV})$ compared with the reported values due to the particle size and quantum confinement effect. $\mathrm{Ag}_{2} \mathrm{O}$ NPs shows an excellent antibacterial activity assay against $E$. coli, $S$. aureus, and $P$. aeruginosa better than antifungal activity assay against Penicillium spp., Aspergillus spp., and Candida albicans. Also, the antimicrobial activity assay of Lawsonia inermis plant extracts is less than green-synthesis $\mathrm{Ag}_{2} \mathrm{O}$ NPs.

Acknowledgement: The experimental parts were supported by the College of Science/Wasit University/Iraq. The physicochemical characterization (i.e., GIXRD, FE-SEM, EDX, FTIR, and UV-Vis) of $\mathrm{Ag}_{2} \mathrm{O}$ NPs was supported by the central laboratory of the University of Tehran/Tehran/Iran.

Funding information: The authors state no funding involved.
Author contributions: All authors have accepted responsibility for the entire content of this manuscript and approved its submission.

Conflict of interest: The authors state no conflict of interest.

\section{References}

[1] Amin M, Anwar F, Janjua MRSA, Iqbal MA, Rashid U. Green synthesis of silver nanoparticles through reduction with Solanum xanthocarpum L. berry extract: characterization, antimicrobial and urease inhibitory activities against Helicobacter pylori. Int J Mol Sci. 2012;13(8):9923-9941.

[2] Velmurugan P, Lee S-M, Cho M, Park J-H, Seo S-K, Myung H, et al. Antibacterial activity of silver nanoparticle-coated fabric and leather against odor and skin infection causing bacteria. Appl Microbiol Biotechnol. 2014;98(19):8179-8189.

[3] Bhakya S, Muthukrishnan S, Sukumaran M, Muthukumar M, Kumar ST, Rao M. Catalytic degradation of organic dyes using synthesized silver nanoparticles: a green approach. J Bioremediat Biodegrad. 2015;6(5):1.

[4] Hutchison JE. Greener nanoscience: a proactive approach to advancing applications and reducing implications of nanotechnology. ACS nano. 2008;2(3):395-402.

[5] Jadhav MS, Kulkarni S, Raikar P, Barretto DA, Vootla SK, Raikar US. Green biosynthesis of $\mathrm{CuO} \& \mathrm{Ag}-\mathrm{CuO}$ nanoparticles from Malus domestica leaf extract and evaluation of antibacterial, antioxidant and DNA cleavage activities. New J Chem. 2018;42(1):204213.

[6] Yadi M, Mostafavi E, Saleh B, Davaran S, Aliyeva I, Khalilov R, et al. Current developments in green synthesis of metallic nanoparticles using plant extracts: a review. Artif Cells Nanomed Biotechnol. 2018;46(sup3):S336-S343.

[7] Manikandan V, Jayanthi P, Priyadharsan A, Vijayaprathap E, Anbarasan PM, Velmurugan P. Green synthesis of $\mathrm{pH}$-responsive $\mathrm{Al}_{2} \mathrm{O}_{3}$ nanoparticles: Application to rapid removal of nitrate ions with enhanced antibacterial activity. J Photochem Photobiol A. 2019;371:205-215.

[8] Raffi M, Hussain F, Bhatti TM, Akhter JI, Hameed A, Hasan MM. Antibacterial characterization of silver nanoparticles against $E$. coli ATCC-15224. J Mater Sci Technol. 2008;24(2):192-196.

[9] Sondi I, Salopek-Sondi B. Silver nanoparticles as antimicrobial agent: a case study on $E$. coli as a model for Gram-negative bacteria. J Colloid Interface Sci. 2004;275(1):177-182. 
[10] Hsin Y-H, Chen C-F, Huang S, Shih T-S, Lai P-S, Chueh PJ. The apoptotic effect of nanosilver is mediated by a ROS-and JNKdependent mechanism involving the mitochondrial pathway in NIH3T3 cells. Toxicol Lett. 2008;179(3):130-139.

[11] Song HY, Ko KK, Oh LH, Lee BT. Fabrication of silver nanoparticles and their antimicrobial mechanisms. Eur Cells Mater. 2006;11(Suppl 1):58.

[12] Sambhy V, MacBride MM, Peterson BR, Sen A. Silver bromide nanoparticle/polymer composites: dual action tunable antimicrobial materials. J Am Chem Soc. 2006;128(30):9798-9808.

[13] Xiang S, Ma X, Shi H, Ma T, Tian C, Chen Y, et al. Green synthesis of an alginate-coated silver nanoparticle shows high antifungal activity by enhancing its cell membrane penetrating ability. ACS Appl Bio Mater. 2019;2(9):4087-4096.

[14] Panáček A, Kvitek L, Prucek R, Kolář $M$, Večeřová R, Pizúrová $N$, et al. Silver colloid nanoparticles: synthesis, characterization, and their antibacterial activity. J Phys Chem B. 2006;110(33):1624816253.

[15] Flores-Lopez NS, Cervantes-Chávez JA, Téllez de Jesús DG, CortezValadez M, Estévez-González M, Esparza R. Bactericidal and fungicidal capacity of $\mathrm{Ag}_{2} \mathrm{O} / \mathrm{Ag}$ nanoparticles synthesized with Aloe vera extract. J Environ Sci Health A. 2021;1-7.

[16] Ghojavand S, Madani M, Karimi J. Green synthesis, characterization and antifungal activity of silver nanoparticles using stems and flowers of felty germander. Journal of Inorganic and Organometallic Polymers and Materials. 2020;30(8):2987-2997.

[17] Haq S, Yasin KA, Rehman W, Waseem M, Ahmed MN, Shahzad $\mathrm{MI}$, et al. Green synthesis of silver oxide nanostructures and investigation of their synergistic effect with moxifloxacin against selected microorganisms. J Inorg Organomet Polym Mater. 2021;31(3):1134-1142.

[18] Aravind M, Ahmad A, Ahmad I, Amalanathan M, Naseem K, Mary SMM, et al. Critical green routing synthesis of silver NPs using jasmine flower extract for biological activities and photocatalytical degradation of methylene blue. J Environ Chem Eng. 2021;9(1):104877.

[19] Laouini SE, Bouafia A, Soldatov A v, Algarni H, Tedjani ML, Ali $\mathrm{GAM}$, et al. Green Synthesized of $\mathrm{Ag} / \mathrm{Ag}_{2} \mathrm{O}$ Nanoparticles Using Aqueous Leaves Extracts of Phoenix dactylifera L. and Their Azo Dye Photodegradation. Membranes. 2021;11(7):468.

[20] Manikandan V, Velmurugan P, Park J-H, Chang W-S, Park Y-J, Jayanthi $P$, et al. Green synthesis of silver oxide nanoparticles and its antibacterial activity against dental pathogens. 3 Biotech. 2017;7(1):72.

[21] Galkina OL, Sycheva A, Blagodatskiy A, Kaptay G, Katanaev VL, Seisenbaeva GA, et al. The sol-gel synthesis of cotton/ $/ \mathrm{TiO}_{2}$ composites and their antibacterial properties. Surf Coat Technol. 2014;253:171-179.

[22] Aziz WJ, Abid MA, Hussein EH. Biosynthesis of CuO nanoparticles and synergistic antibacterial activity using mint leaf extract. Mater Technol. 2020;35(8):447-451.

[23] Bragg WH, Bragg WL. The reflection of X-rays by crystals. Proc Mat Phys Eng Sci. 1913;88(605):428-438.
[24] Aparicio C, Ginebra MP. Biomineralization and biomaterials: fundamentals and applications. Woodhead Publishing; 2015.

[25] Suryanarayana C, Norton MG. X-ray diffraction: a practical approach. Springer Science \& Business Media; 2013.

[26] Kaviya S, Santhanalakshmi J, Viswanathan B, Muthumary J, Srinivasan K. Biosynthesis of silver nanoparticles using Citrus sinensis peel extract and its antibacterial activity. Spectrochim Acta A Mol Biomol Spectrosc. 2011;79(3):594-598.

[27] Paulkumar K, Rajeshkumar S, Gnanajobitha G, Vanaja M, Malarkodi C, Annadurai G. Biosynthesis of silver chloride nanoparticles using Bacillus subtilis MTCC 3053 and assessment of its antifungal activity. Int Sch Res Notices. 2013;2013.

[28] Kumar R, Ashfaq M, Verma N. Synthesis of novel PVA-starch formulation-supported $\mathrm{Cu}-\mathrm{Zn}$ nanoparticle carrying carbon nanofibers as a nanofertilizer: controlled release of micronutrients. J Mat Sci. 2018;53(10):7150-7164.

[29] Vanaja M, Annadurai G. Coleus aromaticus leaf extract mediated synthesis of silver nanoparticles and its bactericidal activity. Appl Nanosci. 2013;3(3):217-223.

[30] Singha S, Neog K, Kalita PP, Talukdar N, Sarma MP. Biological synthesis of silver nanoparticles by Neptunia oleraceae. Int J Basic Appl Biol. 2014;2(2):55-59.

[31] Allahverdiyev AM, Abamor ES, Bagirova M, Rafailovich M. Antimicrobial effects of $\mathrm{TiO}_{2}$ and $\mathrm{Ag}_{2} \mathrm{O}$ nanoparticles against drugresistant bacteria and leishmania parasites. Future Microbiol. 2011;6:933-940.

[32] Neuberger T, Schöpf B, Hofmann H, Hofmann M, von Rechenberg B. Superparamagnetic nanoparticles for biomedical applications: possibilities and limitations of a new drug delivery system. J Magn Magn Mater. 2005;293(1):483-496.

[33] Stoimenov PK, Klinger RL, Marchin GL, Klabunde KJ. Metal oxide nanoparticles as bactericidal agents. Langmuir. 2002;18(17):6679-6686.

[34] Morens DM, Fauci AS. Emerging infectious diseases: threats to human health and global stability. PLoS Pathog. 2013;9(7):e1003467.

[35] Jin S, Ye K. Nanoparticle-mediated drug delivery and gene therapy. Biotechnol Prog. 2007;23(1):32-41.

[36] D’Agata EMC, Magal P, Olivier D, Ruan S, Webb GF. Modeling antibiotic resistance in hospitals: the impact of minimizing treatment duration. J Theor Biol. 2007;249(3):487-99.

[37] Rokade AA, Patil MP, Yoo S, Lee WK, Park SS. Pure green chemical approach for synthesis of $\mathrm{Ag}_{2} \mathrm{O}$ nanoparticles. Green Chem Lett Rev. 2016;9(4):216-222.

[38] Maheshwaran G, Bharathi AN, Selvi MM, Kumar MK, Kumar RM, Sudhahar S. Green synthesis of Silver oxide nanoparticles using Zephyranthes Rosea flower extract and evaluation of biological activities. J Environ Chem Eng. 2020;8(5):104137.

[39] Normani S, Dalla Vedova N, Lanzani G, Scotognella F, Paternò GM. Bringing the interaction of silver nanoparticles with bacteria to light. Biophys Rev. 2021;2(2):021304. 